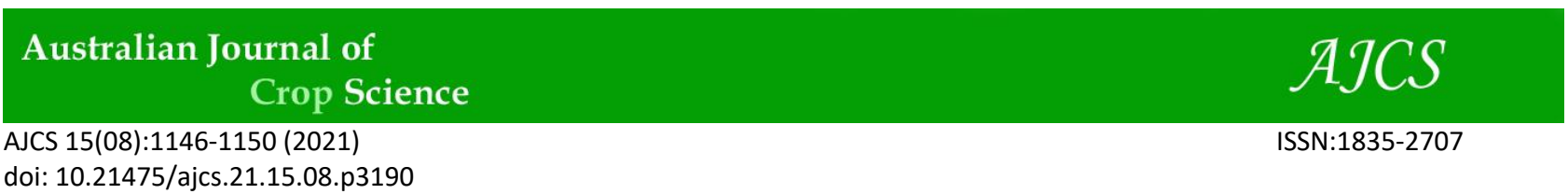

doi: 10.21475/ajcs.21.15.08.p3190

\title{
Silicon as mitigator of salt stress in mango tree seedlings
}

\author{
Mário Leno Martins Véras ${ }^{{ }_{1}}$, Lunara de Sousa Alves ${ }^{2}$, Toshik larley da Silva ${ }^{3}$, lana Nogueira da Silva ${ }^{1}$, \\ Amanda Stefanne do Nascimento da Costa ${ }^{1}$, Edinete Nunes de Melo ${ }^{2}$, Hellen Patricia Lemos Cordovil ${ }^{1}$, \\ Adriana Pricilla Jales Dantas ${ }^{2}$, Nelto Almeida de Sousa ${ }^{4}$, Thiago Jardelino Dias ${ }^{2}$
}

\author{
${ }^{1}$ Federal Institute of Amapá, Highway BR 210 - km 103, 68997-000, Porto Grande, AP, Brazil \\ ${ }^{2}$ Federal University of Paraíba, Department of Phytotechnics and Environmental Sciences, Highway BR 079 - km 12, \\ 58397-000, Areia, PB, Brazil
}

${ }^{3}$ Federal University of Viçosa, Department of Phytotechnics, Avenue Peter Henry Rolfs, University Campus, 36570900, Viçosa, MG, Brazil

${ }^{4}$ Federal University of Santa Maria, Building 77, Room 05, Roraima no 1000, Camobi Neighborhood, 97105-900, Santa Maria, RS, Brazil

\section{*Corresponding author: mario.veras1992@gmail.com}

\begin{abstract}
The use of saline water dramatically reduces the growth and development of plants. Thus, salt stress mitigation can be important to allow the use of this water in the agriculture. This study aimed to evaluate the effect of silicon as attenuators of effects caused by salt stress on seedlings of "Espada" mango tree variety. An experiment was conducted under completely randomized experimental design in a factorial scheme $(5 \times 2)$. The factors studied consisted of silicon concentrations $\left(0,50,100,150\right.$ and $\left.200 \mathrm{mg} \mathrm{L}^{-1}\right)$ and irrigation with low water $\left(0.8 \mathrm{dS} \mathrm{m}^{-1}\right)$ and high $\left(6 \mathrm{dS} \mathrm{m}^{-1}\right)$ electrical conductivity and the growth of mango tree seedlings was assessed 70 days after sowing (DAS) by the height, number of leaves, stem diameter, dry matter of root, aerial part and total, dry matter content, Dickson Quality Index and Index of tolerance to salinity. The application of silicon via leaf mitigates the deleterious effects of salt stress in mango seedlings. Silicon $200 \mathrm{mg} \mathrm{L}^{-1}$ promotes higher growth, dry matter accumulation and $100 \mathrm{mg} \mathrm{L}^{-1}$ concentration provides higher salt tolerance in mango seedlings. Electrical conductivity in the irrigation water at $6 \mathrm{dS} \mathrm{m}^{-1}$ reduce the growth and quality the of mango tree seedlings.
\end{abstract}

Keywords: Mangifera indica L.; salinity; potassium silicate.

Introduction

The nursery stage is one of the most important steps in planting orchards (Mesquita et al, 2012). Thus, studies aiming costs reduction, availability of resources and efficiency in the production of seedlings are extremely relevant (Matos et al., 2016; Albano et al., 2014). However, seedlings production requires good quality of water, and the semi-arid region in the northeast of Brazil there are restrictions on water availability and properties (chemical), specifically for irrigation purposes. Allied to climatic factors such as drought and high evaporation rates there is also the geological material and anthropogenic management (Medeiros et al., 2012), which cause salinization of groundwater and soil, as well as compromising the irrigation water quality. Thus, even more good quality of water for irrigation availability is being reduced.

In saline environments plant growth becomes slower due to the interaction between salts and nutrients in the soil, causing changes that may result in damage to plants. With salts excess in the absorption zone of the root cause increase in competitiveness or structural changes of cell membranes. Harmful effect of salinity on the initial growth of seedlings was noted by several authors, for example, Leite et al. (2016) and Ribeiro et al. (2016) yellow passion fruit and Véras et al. (2017) and Melo Filho et al. (2017) in pitomba tree seedlings.
An alternative to mitigate the effect of salt stress is application (Si), which although not considered essential to plants, there are scientific evidences that this element can reduce or mitigate the deleterious effects of abiotic and biotic stresses (Shi et al., 2013). Studies indicate that Si application in species of plant under stress conditions stimulates growth and development (Ashraf et al., 2010; Ali et al., 2012; Mendonça et al., 2013).

However, there is few studies about salt stress mitigation in fruit seedlings, especially in mango. Because of that, the objective was to evaluate the effect of foliar application of silicon in "Espada" mango seedlings under conditions of irrigation with saline water.

Results and Discussion

Influence of treatments on mango seedlings

There was a significant effect on the interaction between silicon concentration and the irrigation water salinity on the variables analyzed, except the stem diameter that presented a significant effect for the isolated factors. The variables: internal concentration of carbon $(\mathrm{Ci})$, stomatal conductance 
(gs), transpiration (E) and liquid photosynthesis rate (A) did not have a significant effect, and therefore will not be presented.

\section{Effect of salinity stress and silicon in the growth of seedlings of mango}

It was observed that the height of mango tree seedlings had grown by increasing silicon concentration (Figure 1A). Irrigation with water of low salinity $(0.8 \mathrm{dS} \mathrm{m}-1)$ promoted $31.67 \%$ increase in mango tree seedlings height given reaching $32.8 \mathrm{~cm}$ with the application of $200 \mathrm{mg} \mathrm{L}-1$ of Si. However, irrigating the mango tree seedlings with water of $6.0 \mathrm{dS} \mathrm{m-1}$ there was a decrease in mango tree seedlings height, there was a minor increase from $15.74 \%$ up to $20.45 \mathrm{~cm}$ in the seedlings that received no silicon application to $23.67 \mathrm{~cm}$ at a concentration of $200 \mathrm{mg} \mathrm{L}-1$ (Figure 1A).

Number of leaves presented similar behavior because increasing salinity on the irrigation water reduced the number of mango tree seedling leaves (Figure 1B). Under irrigation with water of low salinity ( $0.8 \mathrm{dS} \mathrm{m}-1)$ it was observed an increase of $31.57 \%$ in the number of leaves, wherein the maximum value obtained was 13.71 leaves with the application of $200 \mathrm{mg} \mathrm{L-1} \mathrm{silicon} \mathrm{(Figure} \mathrm{1B).} \mathrm{By} \mathrm{irrigating} \mathrm{the}$ plants with high salinity $(6.0 \mathrm{dS} \mathrm{m}-1)$ it was observed that the mango tree seedlings presented a decrease compared with the seedlings irrigated low salinity water even under the silicon application; the largest number of leaves was 23.67 leaves in the seedlings that received $200 \mathrm{mg} \mathrm{L}-1$ of silicon.

The mathematical model quadratic was the model that better adjusted to the stem diameter of the mango tree seedlings according to the regression equation, the maximum value was obtained with the application of $200 \mathrm{mg} \mathrm{L}-1$ silicon, corresponding to $6.0 \mathrm{~mm}$ (Figure 1C). The mango tree seedlings irrigated with water with bigger salinity had reduced stem diameter, yielding $4.73 \mathrm{~mm}$; a reduction of $9.72 \%$ compared to the diameter found in the ECW of $0.8 \mathrm{dS} \mathrm{m}-1$ that was $5.19 \mathrm{~mm}$ (Figure 1D).

This increase in the growth of mango tree seedlings with the application of silicon concentrations is probably due to increased activity of antioxidant enzymes metabolism, especially protecting against the action of free radicals and consequent cell damages, promoting further expansion and cell division, reflecting directly on seedling growth (Dutra et al., 2018; Maia et al., 2015). The mechanisms that explain these results may be related to biochemical, physiological and photosynthetic aspects of plants (Ashraf et al., 2010; Ali et al., 2012; Mendonça et al., 2013).

Working with passion fruit, Costa et al. (2016) observed that the doses of 280 and $550 \mathrm{mg}$ vessel-1 of silicon provides greater plant height and diameter of the stem in passion fruit, corroborating the data obtained in this study. Recent studies have also shown that the application of Si promoted greater growth of many species of plants (canola, soy, wheat, sorghum, tomatoes and corn) submitted to salt stress conditions, providing increase on leaf area, chlorophyll content and improvements in chloroplasts structures, and consequently caused higher photosynthetic activity (Yin et al., 2013; Haghighi \& Pessarakli, 2013; Rohanipoor et al., 2013).

The reduction in the growth of mango tree seedlings under irrigation with water $6 \mathrm{dS}$ m-1 may have been attributed to toxicity caused by excessive absorption of the salts, specially ions such as sodium ( $\mathrm{Na}+)$ and chloride $(\mathrm{Cl}-)$, which by interacting with the nutrients present in the soil results in nutritional imbalances in plants (Alves et al., 2017; Rahimi et al., 2012; Hasanuzzaman et al., 2013; Véras et al., 2018), interfering in the growth of mango tree seedlings.

\section{Effect of salinity stress and silicon in the dry mass accumulation, seedlings quality and salinity tolerance}

Irrigation with water ECw $0.8 \mathrm{dS} \mathrm{m}-1$ promoted the highest values for these variables compared to irrigation water $6.0 \mathrm{dS}$ $\mathrm{m}-1$, which reduced the dry matter of the mango tree seedlings; the highest values for dry matter of root, dry matter of aerial part and total were $1.52 \mathrm{~g}$ (Figure 2A), $6 \mathrm{~g}$ (Figure 2B) and 7.52 (Figure $2 \mathrm{C}$ ) g respectively in plants irrigated with water $0.8 \mathrm{dS} \mathrm{m}-1$. Under conditions of high salinity $(6.0 \mathrm{dS} \mathrm{m}$ 1) by applying silicon $200 \mathrm{mg} \mathrm{L-1}$ on mango tree seedlings, notice that there was additions of 23.78 and $18.05 \%$ on dry matter of aerial part and dry matter total compared to the seedlings that did not receive silicon application. For dry matter of root was found that the application of silicon provided no addition.

The mango tree seedlings irrigated with higher salinity and without application of silicon in water presented $52 \%$ dry matter content, however, applying the higher silicon concentration ( $200 \mathrm{mg} \mathrm{L}-1)$ there was an increase of $8.22 \%$ in the content of dry matter, yielding $60.32 \%$. It was observed that the highest content of dry matter was obtained in plants irrigated with water of low salinity and application of $200 \mathrm{mg}$ L-1 of silicon with a content of dry matter of $66.69 \%$ (Figure 2D).

When irrigating mango tree seedlings with lower salinity water, it has been found that silicon levels increased the dry matter content, gaining value up to $66.69 \%$ with the application of silicon 200 mg L-1 (Figure 2D).

Similarly, this behavior was observed for Dickson Quality Index on which the observed increase according to the increase of Si concentrations up to $200 \mathrm{mg} \mathrm{L}-1$ in both irrigation water, however, the highest values were observed in irrigated seedlings with water lower salinity ( $0.8 \mathrm{dS} \mathrm{m}-1)$, obtaining 0.87 index, while the plants irrigated with water of $6 \mathrm{dS} \mathrm{m-1}$ had lower rates of up to 0.74 (Figure $2 \mathrm{E}$ ).

Salt tolerance index, it was observed that the mango tree seedlings irrigated with lower salinity this index presented no significant effect, keeping it constant (100\%). However, mango tree seedlings which received a foliar application of silicon had decreased down to the concentration of $50 \mathrm{mg} \mathrm{L-1}$ (IQD 95\%) with a subsequent increase (IQD 100\%) at a concentration of $200 \mathrm{mg} \mathrm{L}-1$ in seedlings that had received a foliar application of silicon (Figure 1F).

The reduction in dry matter accumulation of mango tree seedlings is due to decrease in osmotic potential added to the soil solution and the excess salts accumulation, inhibiting seedlings water absorption, and as a result plants require more energy effort to absorption of water and nutrients, reducing thus, growth and biomass accumulation (Melo Filho et al., 2016; Smith, 2012).

As noted in this study, in several studies it has been shown that silicon promotes higher growth and photosynthetic activity (Yin et al., 2013). This is because the silicon becomes leaves more erect, allowing greater absorption of $\mathrm{CO} 2$, and consequently higher photosynthetic efficiency. The accumulation of silicon on the leaf surface may have promoted a physical barrier in the leaves of sugar beet plants, performing an important role in osmotic adjustment (Heckman, 2013; Cantuário et al., 2014). The decrease in growth and dry matter accumulation has been observed in several works on the 

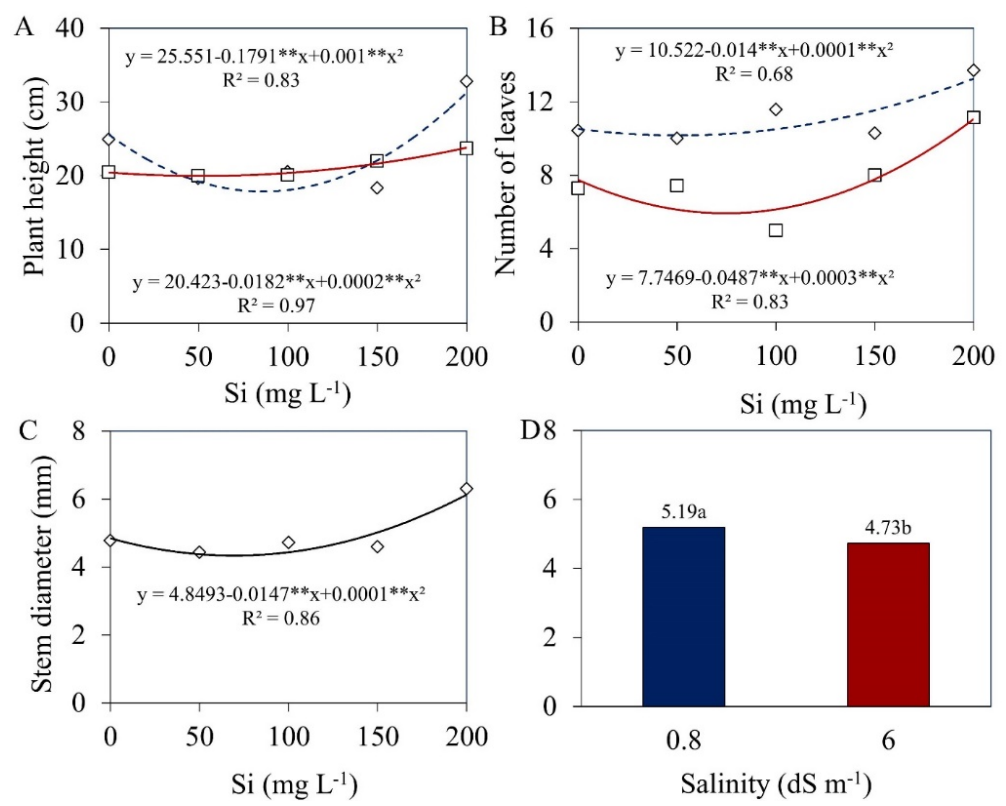

Figure 1. Seedling height (A), number of leaves (B) and stem diameter (C and D) of mango tree seedlings under silicon concentrations and irrigation water of different salinities, $6.0 \mathrm{dS} \mathrm{m}^{-1}(\mathbf{m})$ and $0.8 \mathrm{dS} \mathrm{m}^{-1}(\bullet)$.
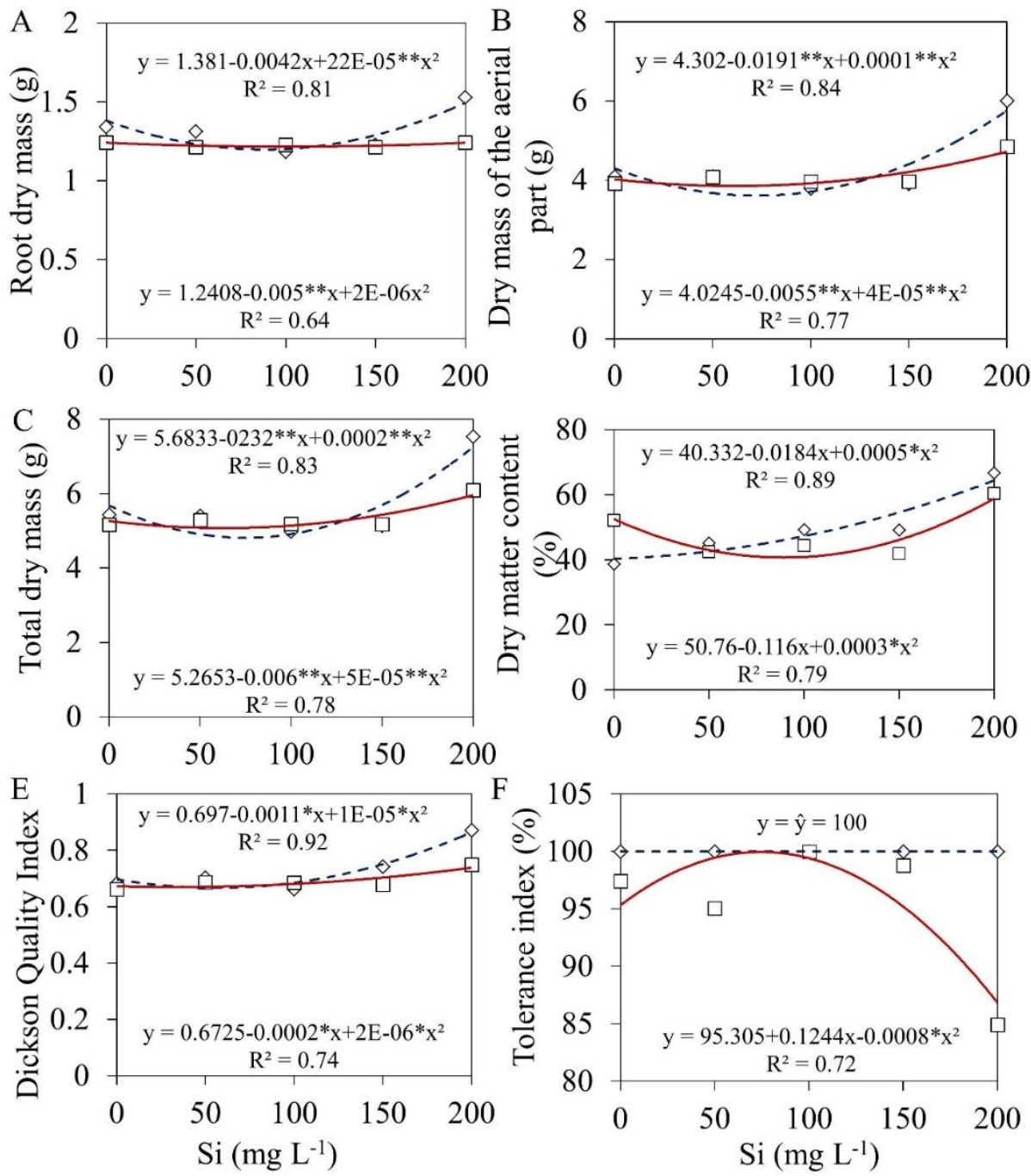

Figure 2. Root dry mass (A), leaves dry mass (B), total dry mass (C), dry matter content (D), Dickson Quality Index "DQI" (E) and Salinity Tolerance Index (F) of mango tree seedlings under silicon concentrations and irrigation with water of different salinities, 6.0 dS $\mathrm{m}^{-1}$ (घ) e $0.8 \mathrm{dS} \mathrm{m} \mathrm{m}^{-1}$ 
production of fruit seedlings, for example, in papaya (Leite et al. 2016; Ribeiro et al. 2016), in

yellow passion fruit (Costa et al., 2016) and Véras et al. (2017) and Melo Filho et al. (2017) in pitomba seedlings.

The highest salt tolerance in mango tree seedlings irrigated with saline water allied to the application of $100 \mathrm{mg} \mathrm{L-1}$ is due to stomatal closure, because this is a major mechanism of plants tolerance to salt stress. In saline conditions plants close their stomata to reduce the accumulation of salts in the plant tissue. This allows the plant tolerates salinity, without causing damage (Yin et al., 2013).

\section{Materials and Methods}

\section{Experimental area location and design}

This experiment was conducted from March to June 2019 in a protected environment at the State University of Paraíba (UEPB), Department of Agriculture and Exact, located in the municipality Catolé do Rocha-PB, Brazil, with the geographical coordinates of $6^{\circ} 20^{\prime} 38^{\prime}$ "South Latitude and $37^{\circ} 44^{\prime} 48$ "West Longitude with an average altitude of $275 \mathrm{~m}$.

The experimental design was completely randomized presenting factorial scheme $2 \times 5$, with seven repetitions. The studied factors consisted of silicon concentrations applied in leaves seedlings $(0,50,100,150$ and $200 \mathrm{mg} \mathrm{L}-1)$ and irrigation with low water ( $0.8 \mathrm{dS} \mathrm{m}-1)$ and high $(6 \mathrm{dS} \mathrm{m}-1)$ electrical conductivity. Those experimental units were comprised of three seedlings cultivated in polyethylene bags with a capacity of $2 \mathrm{dm}^{3}$.

\section{Plant material and the soil preparation}

Mango seeds of "Espada" variety were manually extracted from mango ripe fruit harvested of healthy and vigorous plants in a orchad belonging to the Campus IV of the State University of Paraíba - UEPB. After extraction, the seeds were dried in shade and they have had removed endocarp that wraps the kernel. Subsequently, the seeds were sown in polyethylene bags $(20 \times 30 \mathrm{~cm})$ containing soil. After ten days of emergency (DAE) thinning was done, leaving only one seedling per bag. The soil used for filling of polyethylene bags was collected in the 0 to $20 \mathrm{~cm}$ in native area located at UEPB campus and was classified as Fluvic Neosol with sandy clay loam texture. Samples were taken for chemical analysis, which presented the following characteristics: $\mathrm{pH}=6.85 ; \mathrm{Ca}=4.63 \mathrm{cmolc} \mathrm{dm}-3$; $\mathrm{Mg}=2.39 \mathrm{cmolc} \mathrm{dm}-3 ; \mathrm{Na}=0.30 \mathrm{cmolc} \mathrm{dm}-3 ; \mathrm{K}=0.76 \mathrm{cmolc}$ $\mathrm{dm}-3$; Sum of bases $=8.08 \mathrm{cmolc} \mathrm{dm}-3 ; \mathrm{H}=0.00 \mathrm{cmolc} \mathrm{dm}-3$; $\mathrm{Al}=0.00 \mathrm{cmolc} \mathrm{dm}-3$; cation exchange capacity $=8.08$ and organic matter $=1.88 \mathrm{~g} \mathrm{~kg}-1$.

\section{Irrigation}

At 15 days (DAS), the mango tree seedlings were watered daily with water with two electrical conductivities (ECW) a lower salinity (0.8 dS m-1) and high salinity (6 dS m-1) levels. They were irrigated daily rising up at the beginning, soil moisture around $70 \%$ of field capacity (FC).

The differents ECW were obtained by addition of sodium chloride $(\mathrm{NaCl})$ into the water from the local supply system, as Rhoades et al. (2000), whereby the amount of salts (Q) was determined by the equation $\mathrm{Q}(\mathrm{mg} \mathrm{L}-1)=\mathrm{ECW} \times 640$, wich $\mathrm{ECW}$ represents the desired value of water electrical conductivity. Water chosen as control presented $0.8 \mathrm{dS} \mathrm{m-1}$ and it was obtained from Amazon water well located next to the experimental area, belonging to UEPB. A portable conductivity meter was used to measure electrical conductivity from mango tree seedlings irrigation water during the experiment.
The water used for irrigation that presented electrical conductivity of $0.8 \mathrm{dS} \mathrm{m}-1$ was analyzed and presented the following characteristics: $\mathrm{pH}=7.53 ; \mathrm{Ca}+2=2.30 \mathrm{cmolc} \mathrm{dm}-3$; $\mathrm{Mg}+2=1.56 \mathrm{cmolc} \mathrm{dm}-3 ; \mathrm{Na}+=4.00 \mathrm{cmolc} \mathrm{dm}-3 ; \mathrm{K}+=0.02$ cmolc $\mathrm{dm}-3$ chloride $=3.90 \mathrm{cmolc} \mathrm{dm}-3$; carbonate $=0.57$ cmolc dm-3; Bicarbonate $=3.85 \mathrm{cmolc} \mathrm{dm}-3 ;$ RAS $=2.88$ (mmolc l-1)1/2.

\section{Silicon application}

An application of silicon was done manually with a manual atomizer having as source potassium silicate (K2SiO3) liquid with $12 \% \mathrm{Si}$ and $15 \% \mathrm{~K} 2 \mathrm{O}$. The application was made weekly, with an amount of seven applications. Doses of (Si) were diluted in $1.2 \mathrm{~L}$ of distilled water and then $50 \mathrm{ml}$ of that solution was applied to each plant every application.

\section{Analyzed variables}

The growth of mango tree seedlings was assessed 70 days after sowing (DAS) by the height change measurements with the aid of tape graduated in $\mathrm{cm}$; number of leaves obtained by counting; Stem diameter at breast height (DAS) measured with a digital caliper two $\mathrm{cm}$ above the plant breast, dry matter of root, aerial part and total, dry matter content, Dickson Quality Index (DQI) and Index of tolerance to salinity. The following were also analyzed: leaf gas exchange 45 days after sowing by determining the internal concentration of carbon ( $\mathrm{Ci}$ ) ( $\mu \mathrm{mol} \mathrm{m-}$ $2 \mathrm{~s}-1$ ), stomatal conductance (gs) (mol of $\mathrm{H} 2 \mathrm{O} \mathrm{mol} \mathrm{m-2} \mathrm{s-1),}$ transpiration (E) (mmol of $\mathrm{H} 2 \mathrm{O} \mathrm{mol} \mathrm{m-2} \mathrm{s-1)}$ ) and liquid photosynthesis rate (A) ( $\mu \mathrm{mol}$ of $\mathrm{CO} 2 \mathrm{~m}-2 \mathrm{~s}-1$ ) using the infrared gas analyzer (IRGA) model LCpro + Sistem.

The dry matter of root, aerial part and total were obtained after weighing their roots, stems and leaves, which remain 48 hours in an oven with forced air circulating to a temperature of $60^{\circ} \mathrm{C}$ until obtaining a constant weight measured in scale precision of $0.00001 \mathrm{~g}$. The total dry mass was obtained by adding all dry parts of the plant (stem, leaf and root).

The Dickson Quality Index was obtained according to the methodology Dickson et al. (1960). Total dry matter production data were used to calculate partitioned percentages between vegetative organs and salinity tolerance index, by comparing the saline treatment data with the control $\mathrm{ECW}=0.8 \mathrm{dS} \mathrm{m}-1$, according to methodology Aquino et al. (2007).

\section{Statistical analysis}

Obtained data were evaluated by analysis of variance by $F$ test at probabiblity of 0.05 and 0.01 and in significance cases there was linear and quadratic polynomial regression analysis using the statistical software SAS $^{\circledR}$ (Cody, 2015).

\section{Conclusions}

Application of silicon via foliar mitigates the deleterious effects of salt stress in mango tree seedlings. The silicon dose of $200 \mathrm{mg} \mathrm{L}-1$ promotes higher growth, dry matter accumulation and the dose of $100 \mathrm{mg} \mathrm{L-1}$ provides higher salt tolerance in mango tree seedling. The electrical conductivity in the irrigation water above $0.8 \mathrm{dS} \mathrm{m}-1$ is sufficient to reduce the growth and quality of mango tree seedlings. 


\section{References}

Albano FG, Marques AS, Cavalcante ÍHL (2014) Substrato alternativo para produção de mudas de mamoeiro formosa (cv. Caliman). Científica. 42(4): 388-395.

Ali A, Basra SM, Hussain S, Iqbal J (2012) Increased growth and changes in wheat mineral composition through calcium silicate fertilization under normal and saline field conditions. Chil. J Agric Res. 72(1): 98-103.

Alves LS, Véras MLM, Araújo DL, Melo Filho JS, Irineu THS, Andrade R (2017) Electric conductivity levels in irrigation water and application of biofertilizer in peanut $\mathrm{Br} 1$ crops. Comunicata Sci. 8(2): 347-355.

Aquino AJSD, Lacerda CFD, Bezerra MAEAT, Gomes Filho E, Costa RNT (2007) Crescimento, partição de matéria seca e retenção de $\mathrm{Na}+, \mathrm{K}+$ e $\mathrm{Cl}$ - em dois genótipos de sorgo irrigados com águas salinas. Rev Bras Ciênc Solo. 31(5): 961971.

Ashraf M, Afzal M, Ahmed R, Mujeeb F, Sarwar A, Ali L (2010) Alleviation of detrimental effects of $\mathrm{NaCl}$ by silicon nutrition in salt-sensitive and salt-tolerant genotypes of sugarcane (Saccharum officinarum L.). Plant Soil. 326(1): 381-391.

Cantuário FS, Luz JMQ, Pereira AIA, Salomão LC, Rebouças TNH (2014) Podridão apical e escaldadura em frutos de pimentão submetidos a estresse hídrico e doses de silício. Hort Bras. 32(2): 215-219.

Cody R (2015) An Introduction to SAS University Edition. Cary, NC. SAS Institute, 366p.

Dickson A, Leaf AL, Hosner JF (1960) Quality appraisal of white spruce and white pine seedling stock in nurseries. For Chron. 36(1): 10-13.

Dutra KOG, Silva Irineu TH, Véras MLM, Figueredo JP, Silva JN, Andrade R, Meneses CHSG (2018) Biochemical alterations of red rice cultivated at soil water levels and organomineral fertilization. Comunicata Sci. 9(2): 185-193.

Haghighi M, Pessarakli M (2013) Influence of silicon and nanosilicon on salinity tolerance of cherrytomatoes (Solanum lycopersicum L.) at early growth stage. Sci Hortic. 161: 111117.

Hasanuzzaman M, Nahar K, Fujita M (2013) Plant Response to Salt Stress and Role of Exogenous Protectants to Mitigate Salt-Induced Damages. In: AHMAD, P. et al. (eds.), Ecophysiology and Responses of Plants under Salt Stress. 2587p.

Heckman (2013) Silicon: a beneficial substance. Better Crops 97(4): 14-16.

Leite MJH, Gomes ADV, Santos RV, Araújo JL (2016) Crescimento do maracujazeiro amarelo em função de gesso e compostos com rejeitos de mineralização aplicados em solo salinizado. Nativa. 4(6): 353-359.
Maia JM, Macêdo CEC, Silveira JAG, Silva AF, Lira EHA, Melo AS, Meneses CHSG (2015) Seca e salinidade na resposta antioxidativa de raízes de feijão caupi. J Biol Pharm Agric. Manag. 11(1): 59-93.

Matos RRSS, Silva Jr GB, Souza Marques A, Monteiro ML, Cavalcante ÍHL, Osajima JA (2016) New organic substrates and boron fertilizing for production of yellow passion fruit seedlings. Arch Agron Soil Sci. 62(3): 445-455.

Medeiros SDS, Pinto TF, Hernan Salcedo I, Cavalcante ADMB, Perez Marin AM, Tinôco LBDM (2012) Sinopse do censo demográfico para o semiárido brasileiro. Instituto Nacional de Seminário (INSA), 103p.

Melo Filho JS, Véras MLM, Alves LS, Silva TI, Melo Gonçalves AC, Dias TJ (2017) Salinidade hídrica, biofertilizante bovino e cobertura vegetal morta na produção de mudas de pitombeira (Talisia esculenta). Sci Agrar. 18(3): 131-145.

Melo Filho JS, Veras MLM, Alves LS, Sousa NA, Cavalcante LM, Melo EN, Neto ACG (2016) Growth indexes, production and tolerance of peanut irrigated with saline water and bovine biofertilizer. Afr J Agric Res. 11(44): 4470-4479.

Mendonça AO, Tavares LC, Brunes AP, Monzón DLR, Villela FA (2013) Acúmulo de silício e compostos fenólicos na parte aérea de plantas de trigo após a adubação silicatada. Biosci J. 29(5): 1154-1162.

Rhoades J, Kandiah A, Mashali AM (2000) Uso de águas salinas para produção agrícola. Campina Grande: UFPB. 117p. (Estudos FAO. Irrigação e drenagem, 48).

Ribeiro AA, Moreira FJC, Seabra Filho M, Menezes AS (2016) Emergência do maracujazeiro amarelo sob estresse salino em diferentes substratos. Braz J Biosyst Eng. 10(1): 27-36.

Rohanipoor A, Norouzi M, Moezzi A, Hassibi P (2013) Effect of silicon on some physiological properties of maize (Zea mays) under salt stress. J Biodivers Environ Sci. 7(20): 71-79.

Shi Y, Wang Y, Flowers TJ, Gong H (2013) Silicon decreases chloride transport in rice (Oryza sativa L.) in saline conditions. J Plant Physiol. 170(9): 847-853.

Véras MLM., Sousa Alves L, Melo Filho JS, Silva Irineu TH, Dias TJ (2017) Growth and dry matter of pitombeira seedlings under salinity levels and application of biofertilizer. Comunicata Sci. 8(3): 486-492.

Yin L, Wang S, Li J, Tanaka K, Oka M (2013). Application of silicon improves salt tolerance through ameliorating osmotic and ionic stresses in the seedling of Sorghum bicolor. Acta Physiol Plant. 35(11): 3099-3107.

Zhang XH, Zhou D, Cui JJ, Ma HL, Lang DY, Wu XL, Li M (2015) Effect of silicon on seed germination and the physiological characteristics of Glycyr rhizauralensis under different levels of salinity. J Hortic Sci Biotech. 90(4): 439-443. 